\title{
The Great Canadian Grain Logistics Crisis of 2013-14 and Its Aftermath
}

Author(s): Peter J. Rimmer AM, Claude Comtois

Source: Journal of International Logistics and Trade 2018; 16(2):57-73

Published by: Jungseok Research Institute of International Logistics and Trade, Inha University

DOI: https://doi.org/10.24006/jilt.2018.16.2.057

The Journal of International Logistics and Trade is an official journal published by Jungseok Research Institute of International Logistics and Trade, Inha University, Korea. JILT welcomes manuscripts that advance the practice and science of logistics, trade, and other related fields.

Frequency: Quarterly (March, June, September, December)

Stable URL: https://www.ejilt.org

The Jungseok Research Institute of International Logistics and Trade is a specialized academic research institute representing Inha University and the Inha Foundation in Korea. The institute aims to become a representative institute in Northeast Asia in the research of logistics and trade.

Stable URL: https://jrieng.inha.ac.kr

(C) Copyright. Jungseok Research Institute of International Logistics and Trade.

This is an Open-Access article distributed under the terms of the Creative Commons Attribution NonCommercial License (http://creativecommons.org/licenses/by-nc/4.0/) which permits unrestricted noncommercial use, distribution, and reproduction in any medium, provided the original work is properly cited 


\title{
Journal of
}

\section{International Logistics and Trade}

\section{The Great Canadian Grain Logistics Crisis of 2013-14 and Its Aftermath}

\author{
Peter J. Rimmer AM ${ }^{a *}$, Claude Comtois ${ }^{\mathrm{b}}$ \\ ${ }^{a}$ School of Culture, History and Language, The Australian National University, Canberra, Australia \\ ${ }^{\mathrm{b}}$ Department of Geography, University of Montreal, Montreal, Canada
}

$\begin{array}{ll}\text { ARTICLE INFO } & \text { ABSTRACT } \\ \begin{array}{l}\text { Article history: } \\ \text { Received 19 June 2018 } \\ \text { Accepted 14 August 2018 }\end{array} & \begin{array}{l}\text { This study revisits the Great Canadian Grain Logistics Crisis of 2013-14 to explore the } \\ \text { competitiveness of the country's grain exports. An approach to comprehending the dilemmas } \\ \text { of the international grain supply chain and trade, and national logistics policy in an era of } \\ \text { multinational corporations, draws upon the literature on global value chain analysis. This } \\ \text { analysis identifies both the grain industry's global and local dimensions. An important }\end{array} \\ \begin{array}{l}\text { Keywords: } \\ \text { Canada }\end{array} & \begin{array}{l}\text { literature on the 'politics' of the supply chain is also called into play to discuss who controls } \\ \text { wrain }\end{array} \\ \begin{array}{l}\text { wogistics } \\ \text { recognizects the key economic actors - producers, grain companies, railway companies, port }\end{array} \\ \text { terminal operators and export buyers - and political struggles between them as they each seek } \\ \text { to chain } & \begin{array}{l}\text { to maximize their self-interest. Policy implications for streamlining logistics operations are } \\ \text { drawn from identifying where changes in the supply chain arrangements have gained or lost }\end{array} \\ & \text { opportunities in export markets, particularly in the Asia-Pacific region. }\end{array}$

\section{Introduction}

\subsection{Context and issues}

Many remember the Great Canadian Grain Logistics Crisis of 2013-14 when a record harvest from higher-thananticipated yields coincided with adverse environmental conditions during the winter months in the northern hemisphere. Besides the bumper crop and bad weather, they can recollect insufficient rail capacity, rail congestion delaying the movement of crops by three-to-six months, failure of the railway companies to meet their quotas and claims by producers that the railway companies privileged the movement of oil rather than grain.

Fewer have contemplated how best to deal with this random shock to the logistics system - the strategic, safe, timely and cost-efficient operations of transporting grain in bulk from farm to final destination. Clearly, the lack of competition in the transport sector did not allow the system to operate in an optimal way during the Crisis, which led to the railway companies being unable to procure temporary stand-by capacity to meet short-term peak demand due to inadequacies in planning the distribution of rail cars. Also, the absence of reciprocal penalties for all parties in the supply chain during the Crisis did not render grain shippers accountable for their performance. This study of the Crisis's implications for logistics operations provides an opportunity to explore the dilemmas of the international grain supply chain and trade, and national logistics policy in an era of multinational corporations.

Inevitably, the prime focus of this study is on 2013-14. However, this is essentially a before-and-after study. Going back in time before the 2013-14 Crisis is restricted to the two previous crop seasons because of the privatization of the Canadian Wheat Board in 2012 led to the emergence of a new market system among producers, grain companies, railways,

\footnotetext{
* Corresponding author: School of Culture, History and Language, ANU College of Asia and the Pacific, The Australian National University, Canberra, ACT, Australia 0200, Email: peter.rimmer@anu.edu.au
} 
port terminal operators, and export buyers and users. Going forward in time is limited by the availability of data to the three crop seasons after the 2013-14 Crisis.

Several issues are raised in studying grain logistics during the 2013-14 Crisis. How did this Crisis affect Canada's participation in the international grain industry's supply chain dynamics at a global level? Besides this overarching issue, more specifically, how did the economic stakeholders - producers, grain companies, railways, port terminal operators, and export buyers and users - react to the Crisis? How have they sought to reposition their activities since the Crisis within the international economy? And how has the Government of Canada responded to the Crisis? Before providing a methodology to address these issues, a theoretical framework needs to be established.

\subsection{Theoretical framework}

The theoretical framework is derived from a global value chain analysis, which has been developed and applied to a range of commodities by a host of contributors since the conceptual framework's formulation in the mid-1990s (Gereffi and Korzeniewicz 1994, Leslie and Reimer 1999, Gereffi and Kaplinsky 2001, Coe et al. 2008, Sturgeon 2001, 2008, Hall et al. 2010). Subsequently Gereffi and Fernandez-Stark $(2011,2016)$ have consolidated these contributions in a Primer that details the chain's three global and three local dimensions derived from the interaction between the pull of consumer value and the push from producer supply.

When the three global dimensions are applied to the international grain trade, they cover: (i) its input-output structure from producer to end-user; (ii) its geographical scope in which Canada ranks as a leading exporter along with Argentina, Australia, Brazil, Kazakhstan, Russia, Ukraine and United States; and (iii) the lead multinational corporations comprising Archer-Daniels-Midland Company (ADM), Bunge Ltd, Cargill Inc., and the Louis Dreyfus Company, known collectively as the ABCD Group that reportedly controls over three-quarters of world output enabling it to determine grain types, trading patterns and sales volumes (Table 1). Although challenged by the rise of multinational retailers, notably Carrefour, Tesco and Walmart, and locally operated buyer operations serving the demand of brewers and millers in China, Japan, Singapore, South Korea and Thailand, the ABCD group has responded by establishing joint ventures in China and Indonesia to maintain its overall dominance.

Table 1. Leading multinational corporations in the grain trade, 2016

\begin{tabular}{ccccc}
\hline Company & $\begin{array}{c}\text { Founded } \\
\text { date }\end{array}$ & $\begin{array}{c}\text { Headquarters } \\
\text { location }\end{array}$ & $\begin{array}{c}\text { Countries } \\
\text { number }\end{array}$ & $\begin{array}{c}\text { Employees } \\
\text { number }\end{array}$ \\
\hline $\begin{array}{c}\text { Archer Daniels Midland } \\
\text { (ADM) Co. }\end{array}$ & 1902 & Chicago, IL, USA & 163 & 32,300 \\
Bunge Ltd & 1818 & White Plains, NY, USA & 40 & 62.4 \\
Cargill Inc. & 1865 & Wayzata, MN, USA & 70 & 32,000 \\
Louis Dreyfus Group & 1851 & Amsterdam, Netherlands & 50 & 155,000 \\
\hline
\end{tabular}

Source: Archer-Daniels-Midland Company 2017, Bunge Limited 2017, Cargill Inc. 2017, Louis Dreyfus Company. (LDC, 2017)

Conversely, the three local dimensions encompass Canada's involvement in the global grain value chain to describe how: (i) producers shift between different stages of the value chain to bring about economic and social upgrading; (ii) the economic conditions covering labor, infrastructure and access to finance, and the social elements encompassing labor availability, skill levels, female participation and access to education, are embedded in the local institutional context embracing labor and tax regulation, subsidies and education and innovation policies that promote or hinder industrial development; and (iii) key industry stakeholders interact in the value chain to upgrade the domestic logistics system handling grain and oilseed exports worth C\$21.2 billion in 2014 (CCGA 2014, Quorum Corporation 2015a).

All six dimensions - global and local - are pertinent to this study, but the order and emphasis in discussing them differ from the Primer. After tracking the movement of grain derived from the four-to-five month growing season through the international logistics system in 2013-14, the twin emphases in this study are on: (i) the pivotal importance of the global governance structure to analyze the point at which value is extracted and by whom; and (ii) the local upgrading of the grain logistics system to address the propensity for recurrent crises in Canada.

\subsection{Methodology}

In studying the effects of the 2013-14 Crisis upon the Canada's logistics system, attention is concentrated upon movements of grain and oilseed from Alberta, Manitoba, Saskatchewan and, to a small extent British Columbia, that account for over four-fifths of the country's exports (Figure 1). Key features of the logistics network involve the movement of grain from producers in these Prairie Provinces by rail over 1,300-1,800 km for clearance through: (i) ports on the west coast, notably Vancouver and Prince Rupert, with shipping links to East, South and Southeast Asia, East Africa, and the West Coast Central and South America; (ii) the port of Thunder Bay and a string of Bay and Lake ports, and St Lawrence ports, particularly for transshipment via Montreal, with connections to West Africa, Europe, Middle East and East Coast 
South America; and (iii) the port of Churchill with a tie to Russia. However, there is a need to go beyond this broad picture of grain flows in Canada during the crop year 2013-14 to delve more deeply into the movement along these welldefined corridors between farm and overseas markets by undertaking an input-output analysis.



Figure 1. Supply chain for all grain exports across Canada featuring ports, modal corridors and markets, 2013-14 (Source: Based on Emerson Report 2015, 156, Quorum Corporation 2015a.) Relative rail movements are in proportion to the size of the arrows (no volumes are given in the original diagram). Some lesser grain producing areas in Ontario and Québec with exports to overseas markets are not shown.

The input-output analysis of grain movement through Canada's logistics system in 2013-14 draws upon contemporary accounts of the Crisis, information from individual firms, reports of the Government of Canada's Crop Logistics Working Group (CLWG, 2014, 2015), and data provided by the Canadian Grain Commission (2017a,b), Statistics Canada (2017a,b), and Quorum Corporation (2017a), an organization charged by the Government with monitoring Canada's Grain Handling and Transportation System (GHTS) since the 2000-01 crop year (Section 2). After this analysis, the governance of the global value chain is discussed, drawing upon economic analyses by Gray (2015), White et al. (2015), Brewin (2016), Brewin et al. (2017), and Torshizi and Gray (2017) to gauge who wins and who loses when the grain logistics system experiences a severe capacity constraint (Section 3). Attention is focused upon the lead global ABCD firms that have been transformed from grain merchants into agricultural value chain managers to gauge their degree of influence over the supply chain in Canada (Clapp 2015). Then the upgrading of the Canadian grain logistics systems following the Crisis is discussed (Section 4). This provides an opportunity to highlight the Government of Canada's policy response to the Crisis, which benefits from being able to reflect upon past crises. Also there is an opportunity to discuss how the logistics system has coped during the 2014-15, 2015-16 and 2016-17 crop seasons, and consider the implications of this case study for the big questions regarding the choice between free market fundamentalism and the interventionist approach by government; the former aims to eliminate all regulation and the latter wishes to return to price stability for rural producers (Section 5). Finally, the results from addressing the series of questions raised at the outset are discussed, before the wider implications of the study for the international supply and demand for grain are considered (Section 6).

\section{Input-output analysis: Anatomy of the 2013-14 crisis}

An examination is made of the grain flows from the farm to overseas markets during the 2013-14 Great Canadian Grain Logistics Crisis. All possibilities are canvassed in the grain handling and transportation system (Figure 2). However, as grain from Canada is shipped free-on-board (fob), monitoring ends once it has passed over the ship's rail. At that point the end user - mill, store or grain buyer - becomes responsible for the cost of shipping, terminal charges and land transport. Tracking the inter-continental export component of the mass of grain through the global value chain, as recognized by the Crop Logistics Working Group (CLWG. 2014), is not an easy task. Besides grain being siphoned off for domestic use within Canada and export to, or through, the United States and Mexico, unrecorded transactions occur. All that can be attempted, therefore, is to identify the movement and throughput at each stage of the global value chain during the 201314 crop year and highlight the commercial relations involved in handling this unprecedented crop from the Prairie producer through the grain elevator corporation, railway, port terminal and shipping company to the end buyer and user 
(i.e. the central spine of Figure 2).

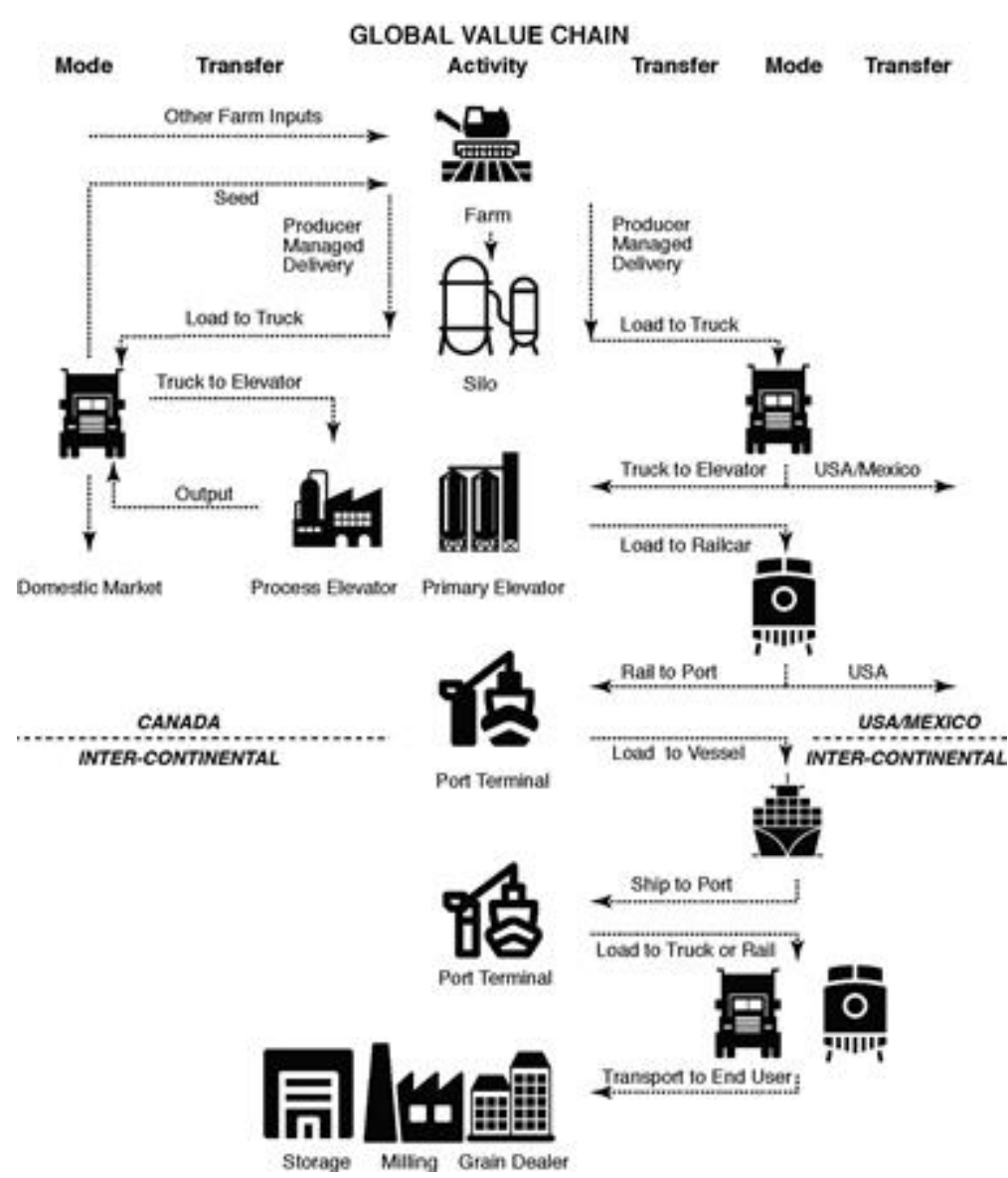

Figure 2. The global value chain. Besides seed other farm inputs used to plant a range of crop species in the spring include herbicides, insecticides, fungicides, fertilizer, fuel, maintenance, labor and insurance

During the autumn of 2013 30,000 Prairie producers harvested a record 77 million tonnes of grains and oilseeds from their spring sowing, comprising mostly wheat used for bread flour, the oilseed canola, and amber durum or pasta wheat (White et al. 2015, 18, Quorum Corporation 2017a). Not only was the output 34 per cent greater than the 56.9 million tonnes produced during the crop year 2012-13 but also it exceeded the previous record of 60.4 million tonnes in 2005-06 by 16.6 million tonnes. With the carryover of 4.9 million tonnes from the 2012-13 crop year, the unprecedented logistics task involved the movement of 81.2 million tonnes. As very little of the harvested grain was moved direct from the farm for processing, it had to be stored on the farm in either permanent steel silos or temporary grain bags or sheds. Then the grain was moved up to $80 \mathrm{~km}$ over the next autumn, winter and spring by the producer's own or hired truck either to domestic grain processors, who converted it into human food or stock feed, or as part of the dominant flow to primary elevators for export. Given the 2013-14 record crop, it was not surprising that the on-farm inventories were bulging.

Primary elevators in 2013-14 received 41.7 million tonnes of the total output for storage, cleaning and out-loading for export, which exceeded the previous year's 34.3 million tonnes by 18.7 per cent. As the storage at the 346 licensed primary elevators located on the railway lines had a capacity of 6.2 million tonnes - less than one tenth of the crop - they quickly became congested in processing the record harvest and had to stop taking deliveries (Quorum Corporation 2014). Average throughput time spent in the primary elevators increased slightly to 29.9 days in 2013-14 compared with 29.5 days during the previous year. As the elevators were primarily geared to providing storage and railway facilities for the onward supply of grain, the logistics system, without a matching supply of rail cars, became backlogged. As early as midSeptember 2013 the logistics system was 1,000 carloads short. By 10 February 2014 51,000 railcar orders were reported to be still left unfulfilled and the backlog experienced in moving the grain into an export position was expected to last until either June or July 2014 (Johnson 2014). As noted by Marowits (2014), this situation heightened tensions and counter claims over responsibility for the shortfall between the grain elevator companies and the railways.

In 2013-14 the country's Class 1 Freight railways were operated by Canadian National (CN) and Canadian Pacific $(\mathrm{CN})$; the only other main line railways involved in the grain trade were the Omni Track Railway in Manitoba linking the port of Churchill and the relevant section of the Burlington Northern Santa Fe (BNSF) railway serving the port of Vancouver (Figure 3). Not only did Canadian National and Canadian Pacific control 85 per cent of route kilometres but 
also they operated within an effective natural monopoly in Canada, because there were few opportunities for interswitching between their respective networks. Consequently, they were obligated under the Fair Rail Freight Act, 2013, to provide services contracted by the shipper that were subject to arbitration when a dispute over terms occurred (Government of Canada 2013). In 2013-14 the railways carried 31.1 million tonnes of grain in 2013-14, which was an increase of 15.6 per cent on the 26.9 million tonnes carried a year earlier. However, the fluidity of the two national railways in handling the record seasonal crop over Western Canada's 28,000 km railway network was undermined by also having to juggle mineral and oil movements from the Prairie Provinces. This issue was compounded during the severe winter, especially in eastern Saskatchewan and Manitoba, which necessitated using shorter train lengths in December 2013 and January 2014 up to 50 per cent less than the usual 110 wagon trains capable of carrying 11,000 tonnes on a two-weekly cycle to and from the port of export. As a result, railway carrying capacity was reduced. On 7 March 2014 this led to intervention by the Government of Canada through an Order in Council to implement an emergency corrective measure embodied in the Canadian Transportation Act, which prescribed a minimum weekly grain target of 536,250 tonnes for both Canadian Pacific and Canadian National to boost greater fluidity in grain movements and ease the backlog on farms and primary elevators (CLWG 2015). By May 2014 this measure was embodied by the Government of Canada (2014) in Bill 30 - Fair Rail for Grain Farmers Act 2014. This Act also invoked fines for not meeting the prescribed target; extended the area of inter-switching between the national railways because most shippers were only served by one company; and sought to enhance service agreements between the grain companies and the railways. Under this regime both Canadian National and Canadian Pacific were fined by the Federal Government C $\$ 100,000$ and C \$50,000 respectively for not meeting their grain quotas (but Canadian Pacific has refused to pay the fine). Nevertheless, this intervention may have slightly increased the speed of rail movements between the primary elevator and the port terminal to an average of 5.3 days in 2013-14 compared with 5.4 days a year earlier.



Figure 3. The Class 1 Freight railway network operated by Canadian National (CN), Canadian Pacific (CP), the Omni Track Railway and the relevant section of the Burlington Northern Santa Fe (BNSF). (Source: Rimmer, 2014: 148) The network of 'shortlines' under the jurisdiction of provincial governments and owned by producer groups to support producer car loading are excluded.

The terminals at the four major export ports - Vancouver, Port Rupert, Thunder Bay and Churchill - experienced an increased flow in 2013-14, as their combined throughput rose by 17.8 per cent to 34.8 million tonnes compared with 29.6 million tonnes during the previous year. On the west coast Vancouver's seven terminals and Port Rupert's single terminal, specialising in bulk or containerized grain destined for the Asia-Pacific region, notably China and Japan, accounted for three quarters of the total throughput. The balance was provided on the east coast by Thunder Bay's six terminals, which concentrated on grain directed to Europe and the Middle East; there was also a small contribution from Churchill's single terminal from which grain was destined for Russia. As a result of the increased throughput at all ports, there was a sharp reduction of time spent in the terminal from 14.3 days to 8.9 days. This was the prime reason for the average time spent in the grain handling and transportation system between primary elevator and the port grain terminal, including time in rail transit, being reduced to 41.1 days in 2013-14 compared with 46.2 days in the previous year. Nevertheless, the flowon effect from the failure to move the record crop was reflected in a 20 per cent decline in the stocks held by the terminals. 
The impact of the 2013-14 Crisis was also manifested in longer delays before ships left port. Shipping lines operating both bulk and containerized vessels were left waiting 12.9 days to load grain at Canada's Pacific ports in 2013-14 compared with 9.7 days during the previous year. In February 2014 Johnson (2014) reported that there 57 ships were sitting at anchor in the west coast ports of Vancouver (40 ships) and Prince Rupert (17 ships) and demurrage was being charged at an estimated C $\$ 25,000$ per day (MacDonald 2014). Not recorded in these statistics were diversions from Vancouver for shipment via the port of Portland in the United States that resulted in a loss of value to Canada.

Buyers and end users of Canadian grain from licensed elevators in 2013-14 were disadvantaged by delays in the justin-time delivery of grain, especially in the major crops of wheat, canola and amber durum. Stretching over 57 countries the importers most badly affected were in major markets within the Western Hemisphere and the Asia-Pacific region (Table 2). Milling establishments in the United States and Mexico, accounting for over 19 per cent of the flow to major importers, failed to receive the required amount of grain when and where required (CLWG 2014, Pedwell 2014). Also negative reputational damage was incurred in the Asia-Pacific region. Although China's Cereals Oils and Foodstuffs Corporation (COFCO) was the largest market, the Japanese Food Agency was badly affected by shipment delays that added 12.5 days to the time required to ship grain there from Canadian ports (Johnson 2014).

Table 1. Major importers of Canadian grains, crop year 2013-14

(000 metric tonnes)

\begin{tabular}{ccccccc}
\hline & Wheat & Amber Durum & Canola & Other $^{1}$ & Total & Per cent \\
\hline USA & $2,108.4$ & 521.4 & 597.1 & $1,898.5$ & $5,125.4$ & 12.8 \\
Mexico & $1,147.0$ & 0 & $1,341.9$ & 34.1 & $2,523.0$ & 6.3 \\
Other Western & $4,003.7$ & 707.0 & 0 & 267.9 & $4,978.6$ & 12.4 \\
Hemisphere & & & & & & \\
Western Hemisphere & $7,259.1$ & $1,228.4$ & $1,939.0$ & $2,200.5$ & $12,267.0$ & 31.5 \\
sub-total & & & & & & 16.4 \\
China P.R. & 633.9 & 0 & $3,932.2$ & $2,026.2$ & $6,592.3$ & 10.8 \\
Japan & $1,590.3$ & 224.8 & $2,130.4$ & 386.8 & $4,332.3$ & 18.9 \\
Other Asia & $4,997.1$ & 207.2 & 540.5 & $1,825.3$ & $7,570.1$ & \\
Asia sub-total & & & & & & 46.1 \\
Europe & $7,221.3$ & 432.0 & $6,603.1$ & $4,238.3$ & $18,494.7$ & 11.7 \\
Africa & 499.6 & $1,360.2$ & 85.9 & $2,757.6$ & $4,703.3$ & 10.7 \\
Total & $2,343.0$ & $1,804.3$ & 0 & 155.3 & $4,302.6$ & 100.00 \\
Per cent & $17,323.0$ & $4,824.9$ & $8,628.0$ & $9,351.7$ & $40,127.6$ & \\
\hline
\end{tabular}

1 Other includes soybeans, peas, barley, oats, lentil, flax corn, canary seed, rye, mustard seed, mixed grain, beans, chick peas, sunflower, triticale, faba beans and pea beans.

Source: Derived from Canadian Grain Commission (2017b): Annual Crop Year Data 2013-14, Tables 1-11.

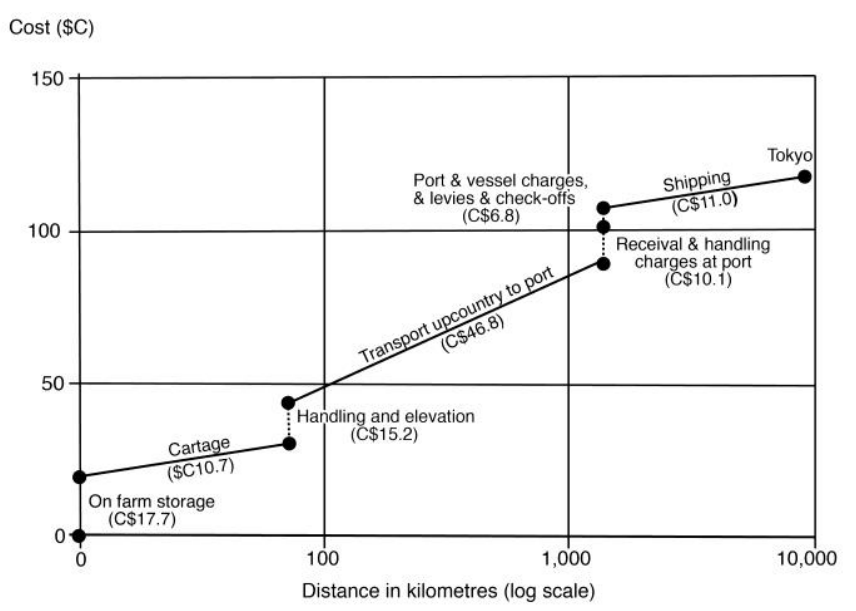

Figure 4. Cost-distance diagram showing segmented costs in the movement of grain from the Canadian province of Saskatchewan to the Port of Tokyo, Japan, 2013-14. (Source: Based on information in White, et al. 2015)

During the Grain Logistics Crisis in 2013-14 the movement from the farm gate in Saskatchewan to the miller in Tokyo, Japan, took an estimated 66.1 days (Figure 4). The total cost of moving wheat 9,000 km from the Prairies to Japan, derived from estimates by White et al (2015) was C\$118.30 per tonne (Figure 4). Almost one-quarter of the total cost was incurred in on-farm storage and trucking the grain from the farm to the primary elevator. Moving the grain from the primary elevator via rail for shipment overseas was, however, the largest cost item accounting for almost over two-thirds of the total cost with transport from upcountry to the port being the largest contributor. Thus over 90 per cent of the cost 
of moving grain was experienced within Canada; the balance was incurred in the shipping leg. No account in these estimates, however, was made of the demurrage charged due to the prolonged delays of shipping in Canadian ports during the 2013-14 Crisis.

In 2013-14 the full effect of the Crisis on overseas markets, however, was masked by a surplus in global grain production. As a result, the export quotation for '1Canada Western Red Spring Wheat (13\% protein)' of C\$327.12 in 2013-14 was only 0.5 per cent lower than the preceding year (Table 3). But the difference (or 'spread') between the export quotation for wheat at the port and the average Prairie grain elevator price, known in Canada as the 'export basis', had increased markedly. Indeed, the export basis, comprising price differential, trucking cost, check-off cost and trucking premiums, rose to the unprecedented level of over C\$131 per tonne in 2013-14 compared with less than C\$54 per tonne during the 2012-13 crop year. Consequently, the producer's netback, based on the average price of grain sold at the port less the export basis, plummeted to less than C\$196 per tonne in 2013-14 compared with over C\$275 per tonne during the preceding year.

Table 3. Calculation of average producer's netback for 1canada red spring wheat, crop years 2011-12, 2012-13 and 2013-14

(C\$/tonne)

\begin{tabular}{cccc}
\hline & $2011-12^{1}$ & $2012-13$ & $2013-14$ \\
\hline Export quotation $^{2}$ & 326.04 & 328.26 & 327.12 \\
Less export basis costs $^{2}$ & & -43.76 & -122.12 \\
Price differential $^{3}$ & -84.99 & -9.82 & -9.82 \\
Trucking to primary elevator $^{4}$ & +8.17 & +0.80 & -0.53 \\
Trucking premiums $^{5}$ & +2.07 & -0.71 & -0.48 \\
Industry check-offs $_{\text {Total }}$ & -0.00 & -53.49 & 131.89 \\
Producer's netback $_{\text {Spot price }}^{6}$ & -74.75 & 275.27 & 195.23 \\
\hline
\end{tabular}

${ }^{1}$ Crop year 2011-12 is the last year wheat was under the control of the Canadian Wheat Board and is not comparable with subsequent years.

${ }^{2}$ Final realized price for 1Canada Western Red Spring Wheat (based on $13.5 \%$ protein).

${ }^{3}$ The price differential covers the cost of freight, handling, cleaning, storage, weighing and inspection, together with an opportunity cost or risk premium.

${ }^{4}$ In 2011-12 the costs of trucking to the primary elevator were paid directly by the grain company to attract business; these benefits have disappeared with the industry's move to an open market.

${ }^{5}$ In 2011-12 an indirect share of transport costs savings was derived from the Canadian Wheat Board but were eliminated in subsequent years with the Board's demise.

${ }^{6}$ The spot price is calculated by subcontracting the price differential from the export quotation.

Source: Quorum Corporation 2002, 2013, 2014, 2015b.

More significant for the spring wheat producer than the producer's netback was the average spot price offered by the grain company because it more closely reflected the open market conditions that followed the demise of the Canadian Wheat Board. During the 2013-14 Crisis the average spot price declined to C $\$ 205.23$ per tonne compared with C $\$ 284.50$ in 2012-13. This lower spot price offered by the grain companies was unfavourable to producers dispatching their grain to the primary elevator. Not only did this lower spot price occasion a cash flow issue and an emotive response from producers but also resulted in an increase in the amount of grain carried over into the next crop year. This carryover increased by 9.8 million tonnes from 4.9 million tonnes in 2012-13 to 14.2 million tonnes in 2014-15. Grain left languishing unsold in farm storages across Western Canada was subject to a deterioration in quality that almost inevitably resulted in a lower price in the following crop year.

The situation suggests that there were no efficiency benefits accruing to the grain companies and railways from the larger crop during the 2013-14 Crisis to offset their fixed costs. Alternatively, the efficiency benefits were, more likely, not passed on to producers, because the dominant Canadian supply chain model exhibited 'near cartel-like' characteristics during 2013-14, particularly as the grain companies exercised their market power and garnered significant rents from producers (Brewin et al. 2017, 3). Lost or deferred revenue by producers over the crop year 2013-14 was calculated at between $\mathrm{C} \$ 2.8$ billion and $\mathrm{C} \$ 4.3$ billion for Canada as a whole (Gray 2015, 13). These circumstances highlight the need to examine the governance of Canada's export supply chain infrastructure to discuss the relative shares of winners and losers in the global value chain during the 2013-14 Crisis, and future implications for deregulating the railways with regard to grain shipments.

\section{Consequences of changes in global governance}

The Canadian Wheat Board, producers, truckers, grain companies, the railway duopoly, port terminal operators and end users and buyers have long been major players in Canada's grain supply chain. However, since 1 August 2012 when the Canadian Wheat Board's monopoly control over movements of wheat and barley was eliminated, the grain elevator companies have assumed the principal role. As the grain companies are now free to compete (or collude) across the supply chain, the producers and railways have been recast as service suppliers (Brewin 2016). Not only do the grain 
companies buy from the Prairie producers but also they negotiate contracts with the shipping companies and market the grain to end users and buyers. This has resulted in the division of Canada's dominant governance structure of the supply chain into two separate segments: a smaller one encompassing producer-trucker-grain company commercial and financial relationships with the dominant connections occurring between the producer and the grain company; and a larger one incorporating grain company-rail-terminal-shipping company-end user commercial and financial relations with the dominant links between grain company and the end user or buyer (Figure 5).

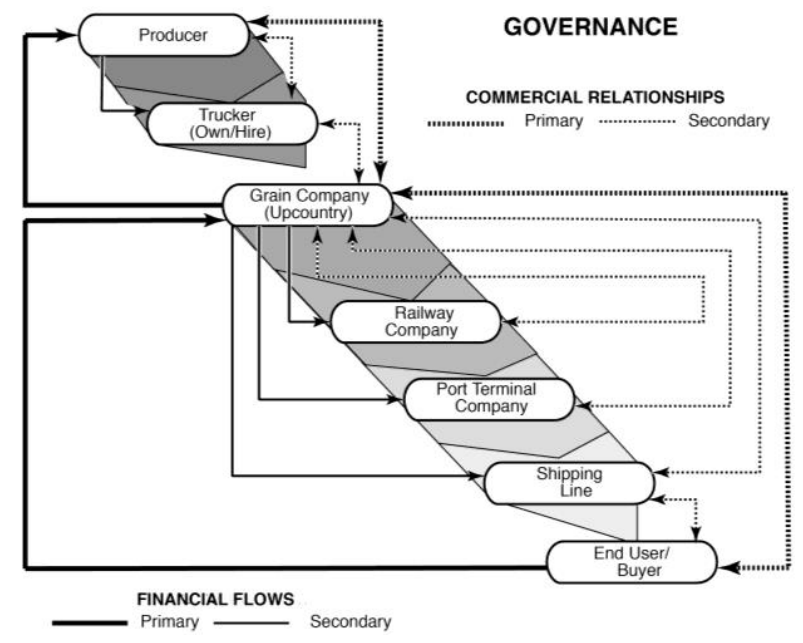

Figure 5. Canada's dominant grain supply system. (Source: Based on Quorum Corporation 2015a)

The smaller governance structure involving the producers and the grain company restricts the proportion of the supply chain from which farmers can derive a direct benefit. By 2013-14 the state-owned pooling cooperatives had transitioned into private hands and the Canada Wheat Board had been privatized. Other than minor assets from shareholdings in inland rail sites and membership of short-line railways, the participation of the producers in the grain supply system was limited to their dealings with the trucking company carrying the grain and the grain company offering the spot price and, if accepted, receiving it. As there was no direct connection with the end user or buyer, the producers received little benefit from any streamlining of the logistics system; their main business was simply the production of grain on which the entire supply chain depends.

Table 4. Major licensed grain companies in Western Canada, 1 August 2013

\begin{tabular}{ccccc}
\hline Company & Founded & Headquarters & \multicolumn{2}{c}{ Primary elevators } \\
\cline { 4 - 5 } & Date & Location & Number & 000 tonnes \\
\hline ABCD Subsidiaries & & & & 30 \\
ADM Agri-Industries Company & 1985 & Windsor, ON & 2 & 57 \\
Bunge Canada & 1992 & Oakville, ON & 30 & 378 \\
Cargill Ltd & 1928 & Calgary, AB & 10 & 1152 \\
Louis Dreyfus Canada Ltd & 1941 & Calgary, AB & 44 & 409 \\
\hline Sub-total & & & 20 & 404 \\
\hline Other Major Companies & 1909 & Winnipeg, MB & 33 & 1,424 \\
Parrish \& Heimbecker Ltd & 1908 & Winnipeg, MB & 66 & 1,537 \\
Paterson Grain & 1857 & Winnipeg, MB & 72 & 3,774 \\
Richardson Pioneer Ltd & 2007 & Regina, SK & 191 & 1,275 \\
Viterra Inc. & & 107 & 6,201 \\
Sub-total & & $342^{1}$ & \\
\hline Other Companies (55) & & & & \\
\hline Total & & &
\end{tabular}

${ }^{1}$ Quorum Corporation (2014) uses the figure 346.

Source: Derived from Canadian Grain Commission, 2013, Table 6.

In the larger governance structure, as in the smaller, the grain companies controlled exports during the 2013-14 crop year, not only by their ownership of the primary elevators but also through their shareholding in port terminal operations and direct dealings with end users and buyers. Prior to the Crisis the Canadian Grain Commission (2013) reported that there were 342 licensed primary elevators owned by 63 licensed companies on 1 August 2013 (Table 4). Ownership ranged from members of cooperatives operating a few small elevators of limited capacity to six large companies. Only two of the six - the long-standing Cargill Inc. and Louis Dreyfus Co. - belonged to the ABCD Group of Companies; the other two Archer Davies Midland (ADM) Co. and Bunge Ltd did not have substantial primary elevator capacity. 
Collectively, the Group owned 13 per cent of the number of companies and over 18 per cent of their capacity. There was, therefore, still a distinctive non-ABCD flavour in the handling, processing and transporting grain in Canada on the eve of the 2013-14 Crisis. This is borne out by contrasting the global and local footprints of the other four dominant companies - Parrish \& Heimbecker Ltd and Paterson Grain, and Richardson Pioneer Ltd and Viterra Inc. - that had over half of the terminals and three-fifths of their capacity.

Both the family firms of Parrish and Heimbecker Ltd and Paterson Grain were established in Winnipeg at the beginning of the twentieth century but their patterns of operations have differed (Figure 6). Parrish and Heimbecker (P\&H 2009, 2016) has been steadfast in confining its grain elevator and trading network within Canada by diversifying from owning its own fleet of ships on the Great Lakes into port terminals before moving from the 1950s into flour milling and feed mills that have underpinned a large associated poultry business. Although Paterson Grain (PG 2016) has maintained a similar Canadian base of elevators, a fleet of ships, trucks, and a port terminal at Thunder Bay, it has also moved into inland export terminals during the 1990s to clean grain on the Prairies, milling and consumer products, and established Paterson GlobalFoods Inc. in 2005 that has extended its marketing operations worldwide.

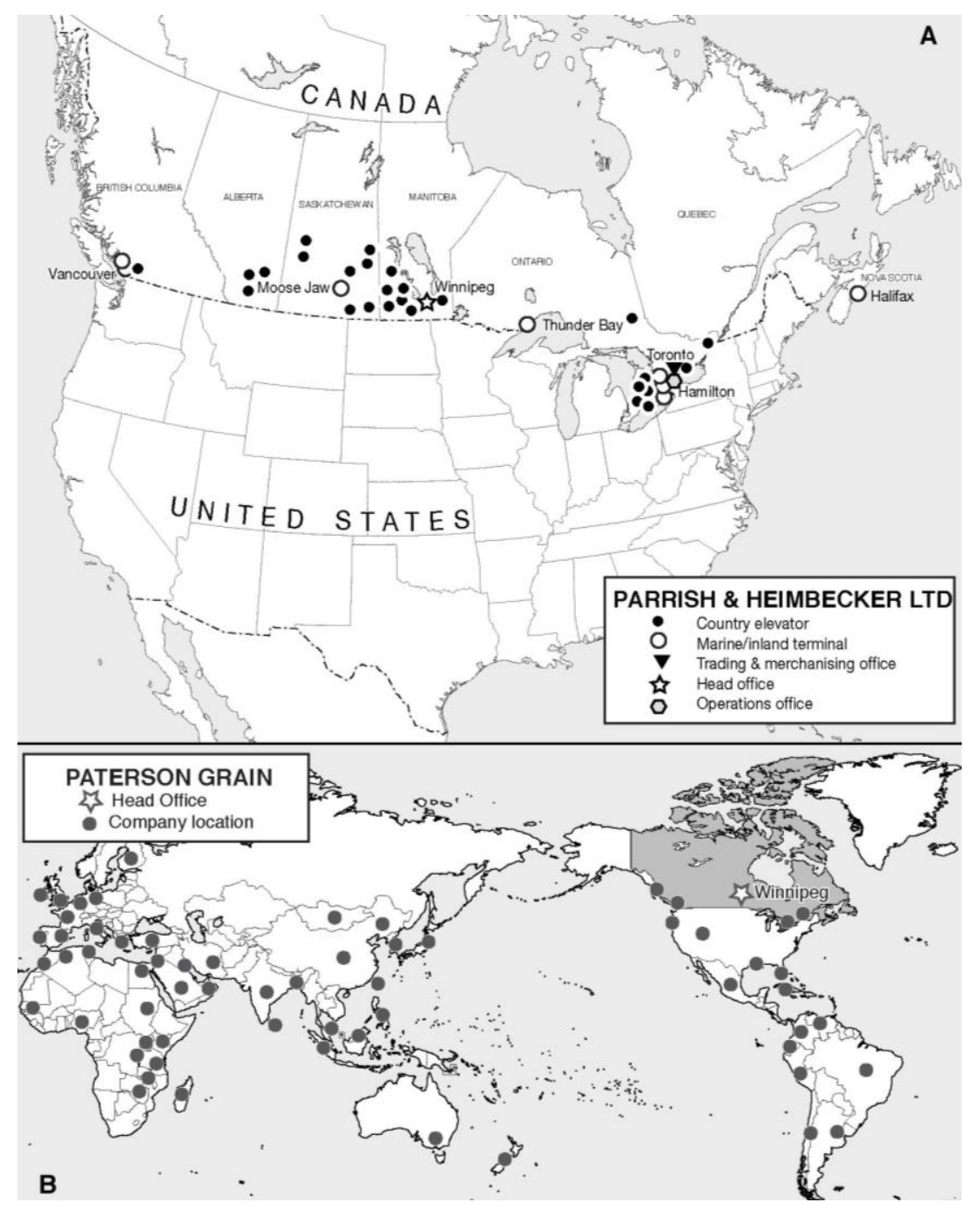

Figure 6. (A) Parrish and Heimbecker Ltd's grain network encompassing elevators and port terminals; not shown are the company's seven flour mills and six feed mills. (Source: P\&H 2016)

(B) Paterson Grain's marketing activities. (Source: PG 2016)

Of the other two firms, Richardson Pioneer is a component of another Winnipeg-based family firm, James Richardson \& Sons Ltd, originally established in Ontario in 1857, whereas Viterra Inc. originated from the transformation of four farmer cooperatives, including the Saskatchewan Wheat Pool established in 1924, into a publicly traded company in 1996 (Figure 7). Richardson (2016) has diversified by moving from owning elevators in the Prairies into oil seeds and milling handled by Richardson International Ltd that, in turn, has extended its operations into the United States and augmented them with ventures into oil and gas exploration, financial services and property management (Silcoff 2017). Once Viterra Inc. assumed its current name in 2007, the company turned its back on a series of past financially disastrous doughnut shops, fish firms and overseas port terminal ventures in Poland and Mexico, to become Canada's 'national champion' 
with the greatest array of grain elevators, specialty plants, outlets and terminals (Nickel and Howley 2012, Gruending 2012). Since then Viterra Inc. has returned to its core grain handling and trading activities, and used these assets to return overseas to acquire grain handling and port operations in Australia, China and New Zealand.

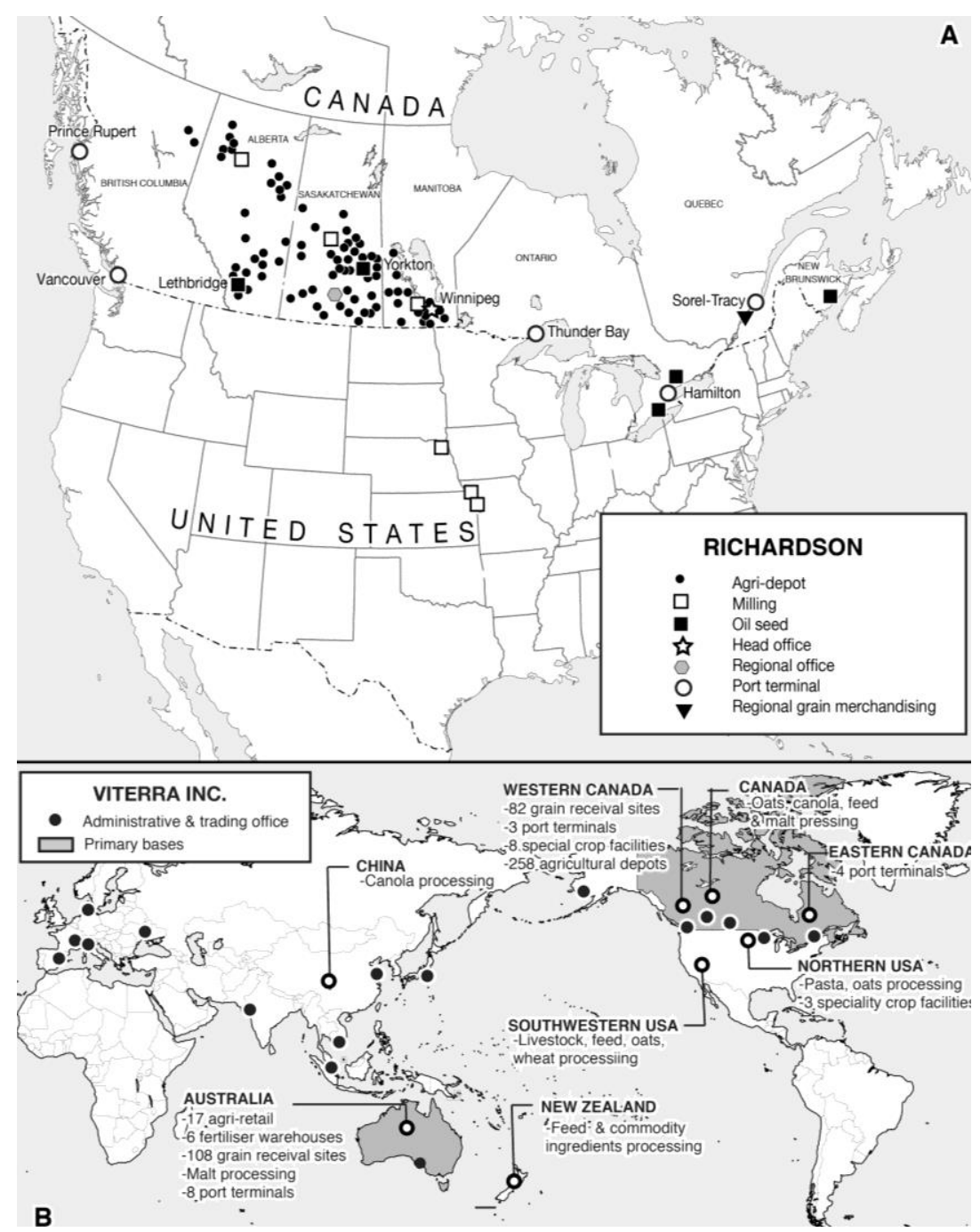

Figure 7. (A) Richardson Pioneer Ltd. (Source: Richardson, 2016);

(B) Global agricultural network of Viterra Inc., 2012. (Source: Nickel and Howley, 2012)

When the termination of the Canadian Wheat Board in 2012 allowed the grain companies to buy wheat and barley direct from producers, Viterra's portfolio became a prime takeover target for the other two ABCD companies - Archer Davies Midland (ADM) Co. and Bunge Ltd - to provide them with a stronger foothold in the primary elevator sector. However, they both lost out to the C\$5.5 billion bid from the Anglo-Swiss multinational trading and mining company Glencore PLC Ltd with its registered office in St Helier, Jersey, and its headquarters in Barr, Switzerland (Briere 2012). Although the Government of Canada had in the past opposed the disposal of assets to foreign interests (e.g. Potash Corporation of Saskatchewan in 2010), the sale of Viterra was made more palatable to the Canadian public by the disposal of some of the company's primary grain elevators to promote Richardson Pioneer Ltd as the new 'national champion'. By the 2013-14 Great Canadian Grain Logistics Crisis., therefore, Viterra Inc. was no longer in a position to dictate the price for the huge crop, as it had done during the previous year, to ensure other companies competed with it for farm deliveries (Brewin 2016).

Also, Viterra's position had been weakened by the enforced disposal of port terminal capacity to Richardson International Ltd as part of the Glencore takeover. Nevertheless, the addition of Glencore to the ABCD Group (ABCD+G) not only gave the enlarged entity a greater proportion of primary elevator capacity but also a larger share of the ownership of Canada's 29 terminals. While both the Group and the major Canadian companies had 8 terminals each on 1 August 2013, the former had almost 45 per cent of the capacity compared with less than 16 per cent for the latter. Even so, the listing did not reveal the true degree of concentration, because the list of licensed port terminal owners did not record their relative shares in cases where the terminals were jointly owned, particularly in Western Canada (e.g. Port Rupert Ltd is owned by Cargill, Glencore and Richardson). As there were fewer entities involved in the ports than in primary 
elevation, the greater concentration enabled owners to negotiate commercial agreements with those grain companies that did not possess terminal capacity and capitalize upon this competitive advantage as major exporters when managing ship queues and determining the loading order. Before considering if further consolidation is likely to increase the $A B C D+G$ Group's dominance in port terminal capacity, it is important to examine interventions by the Government of Canada to streamline the country's logistics system.

Table 5. Licensed port terminals, 1 august $2013^{1}$

\begin{tabular}{|c|c|c|c|c|c|c|}
\hline \multirow[b]{2}{*}{ Company } & \multicolumn{2}{|c|}{ Western Canada } & \multicolumn{2}{|c|}{ Eastern Canada } & \multicolumn{2}{|c|}{ Total } \\
\hline & $\begin{array}{c}\text { Terminals } \\
\text { number }\end{array}$ & $\begin{array}{c}\text { Capacity } \\
000 \text { tonnes }\end{array}$ & $\begin{array}{l}\text { Terminals } \\
\text { number }\end{array}$ & $\begin{array}{c}\text { Capacity } \\
000 \text { tonnes }\end{array}$ & $\begin{array}{l}\text { Terminals } \\
\text { Number }\end{array}$ & $\begin{array}{c}\text { Capacity } \\
000 \text { tonnes }\end{array}$ \\
\hline \multicolumn{7}{|l|}{$A B C D+G$ Group } \\
\hline $\begin{array}{l}\text { ADM Agri-Industries } \\
\text { Company }\end{array}$ & 0 & 0 & 1 & 110 & 1 & 110 \\
\hline Bunge of Canada Ltd & 0 & 0 & 1 & 224 & 1 & 224 \\
\hline Cargill Ltd & 1 & 237 & 2 & 593 & 3 & 830 \\
\hline Louis Dreyfus Canada Ltd & 0 & 0 & 1 & 293 & 1 & 293 \\
\hline Viterra Inc. (Glencore) & 0 & 0 & 2 & 625 & 2 & 625 \\
\hline Sub-total & 1 & 237 & 7 & 1845 & 8 & 2082 \\
\hline \multicolumn{7}{|l|}{ Major Canadian Companies } \\
\hline Parrish \& Heimbecker Ltd & 1 & 15 & 3 & 197 & 4 & 212 \\
\hline Paterson Grain & 0 & 0 & 0 & 0 & 0 & 0 \\
\hline Richardson International & 1 & 108 & 3 & 401 & 4 & 509 \\
\hline Sub-total & 2 & 123 & 6 & 598 & 8 & 721 \\
\hline Other & 6 & 896 & 7 & 867 & 13 & 1763 \\
\hline Total & 9 & 1256 & 20 & 3310 & 29 & 4566 \\
\hline
\end{tabular}

\section{Local upgrading: the government of Canada's response}

Any rationalization of the logistics system in Canada after the 2013-14 Crisis needs to reflect upon past crises that have punctuated the development of the country's transportation and grain marketing over the past 150 years of Federation. In response to these crises the Government of Canada has been galvanized periodically for much of its history into commissioning reports and taking remedial action to offset any suggestion that the country's logistics system had failed producers, grain companies, rail companies, port terminal operators and international traders. Marked policy shifts from free markets to regulation and back again, as highlighted by Earl (2015), have also mirrored cycles in economic thought.

As early as 1897 the Federal Government of Canada intervened in the free market to create the Crow's Nest Pass Agreement with the Canadian Pacific Railway that established statutory freight rates for moving grain from farms in the Prairies to the export ports; this 'Crow Rate' was later extended to the Canadian National Railway (Table 6). During the Great Depression of the 1930s further regulation saw the creation of the Canadian Wheat Board to provide additional logistics oversight of wheat and barley movements. After 1943 the Board single-handedly oversaw the management of publicly owned rail cars for the next 69 years, bargaining with the grain companies to process wheat and barley, negotiating freight rates with the railways, offering prices to buyers at the export ports, and compensating the producers in good years and bad. During this period the 1976 Grain Crisis led to the Hall Commission Report (1977) entitled Grain and Rail in Western Canada, which resulted in the establishment of the Grain Transportation Agency (GTA) in 1979; this was followed by the Western Grain Transportation Review (the Gilson Report 1982) that led to the Western Grain Transportation Act (WGTA) 1984, replacing the statutory freight rates embodied in the Crow's Nest Pass Agreement 1897 with subsidies to move grain from the Prairies to the ports (Gilson 1982, Kroeger 2009). The 1995 Crisis resulted in the WGTA being replaced by the Canadian Transportation Act 1995 and the prescription of maximum allowable rail rates according to distance, which more than doubled the average cost of hauling grain haul and resulted in a diversification in crop patterns (Doan et al. 2006, Brewin et al. 2017). A further disruption of grain movements across Western Canada led to the production of the Estey Report, entitled the Grain Handling and Transportation Review, which recommended that the Canadian Wheat Board adopt a more commercial and competitive logistics system (Estey 1998). In 2000 the fixed rates for grain were converted into a flexible revenue cap, which allowed the railways to charge higher rates for low mass movements and lower rates for bulk movements employing larger rail cars. Then in 2012 the Conservative Government of Canada sought to restore the free market by discontinuing the single-desk powers exercised for wheat and barley movements by the non-profit making Canadian Wheat Board, which had made it illegal for producers to sell their own grain. At first the crop and the competitive conditions that prevailed in 2012-13 appeared to justify this decision to re-establish the free market and contemplate deregulating the railways until the record grain logistics 
bottleneck and impediments to international trade occurred during the following crop year.

Table 6. Government of Canada's responses to grain logistics crises

\begin{tabular}{|c|c|}
\hline Date & Key developments \\
\hline 1897 & $\begin{array}{l}\text { Special Commission: Crow's Nest Pass Agreement between the Federal Government of Canada and the Canadian } \\
\text { Pacific (CP) Railway that fixed tariffs for grain and settler's goods in return for mineral rights. }\end{array}$ \\
\hline 1917 & Canadian National $(\mathrm{CN})$ Railway, established as a crown corporation, also had to offer low freight rates \\
\hline 1925 & 'Crow Rate' made statutory for all railways \\
\hline 1935 & Crisis \\
\hline 1935 & Canadian Wheat Board established \\
\hline 1960 & Crisis: Lack of competition \\
\hline 1961 & MacPherson Royal Commission on Transportation \\
\hline 1967 & National Transport Act (NTA) \\
\hline 1976 & Crisis \\
\hline 1977 & The Hall Report: Grain and Rail in Western Canada \\
\hline 1979 & Grain Transportation Agency (GTA) created \\
\hline 1982 & Gilson Report: Western Grain Transportation, Report on Consultations and Recommendations \\
\hline 1984 & $\begin{array}{l}\text { Western Grain Transportation Act (WGTA) } 1984 \text { replaced Crow's Nest Pass Agreement and subsidized the } \\
\text { movement of grain by rail. }\end{array}$ \\
\hline 1987 & National Transportation Act 1987 sought to enhance the process of deregulation. \\
\hline 1995 & Crisis \\
\hline 1995 & $\begin{array}{l}\text { Canadian Transportation Act led to the dismantling of the Western Grain Transportation Act and the elimination of } \\
\text { the 'Crow' benefit }\end{array}$ \\
\hline 1998 & The Estey Report Grain Handling and Transportation Review \\
\hline 2000 & $\begin{array}{l}\text { Adoption of Bill 34-C resulted in the fixed rates of WGTA being converted into a revenue cap; this Maximum } \\
\text { Revenue Entitlement (MRE) permitted the railways to charge higher rates for expensive movements and offer } \\
\text { preferential rates for bulk movements. }\end{array}$ \\
\hline 2012 & Canadian Wheat Board discontinued by Conservative (Harper) Government of Canada \\
\hline 2013-14 & Great Canadian Grain Logistics Crisis \\
\hline 2015 & $\begin{array}{l}\text { The Emerson Report Canada Pathways: Connecting Canada's Transportation System to the World (review of } \\
\text { Canadian Transportation Act) }\end{array}$ \\
\hline
\end{tabular}

Source: Prabhu (1971), Wilson (1978), Kerr et al. (1991), Schmitz and Furtan (2000), Transport Canada (2001), Kroeger (2009), Doan et al. (2006), Earl (2015), Miner, (2015), Nolan and Peterson (2015), Brewin (2016).

The Government of Canada's reaction to 2013-14 Grain Logistics Crisis has proved to be no different from past crises. Initially, in 2014, the Conservative Government sought a temporary stop-gap measure by implementing changes in its grain-monitoring program. Bill C-30 was enacted by the Government to address some of the immediate issues arising from the Crisis. In particular, rail companies had to report selected data more frequently on their activities, including number of railcars ordered and cancelled by producers, and number of railcars despatched by railways. However, the effect of Bill C-30 was short-lived because the regulations only lasted until August 2014; a more permanent fix had to be sought.

In 2015 the Conservative Government of Canada responded in the time-honoured fashion of commissioning a full review of the Canadian Transportation Act by a former Minister, the Hon. David Emerson. The resultant Emerson Report (2015) recommended removing the last vestiges of the old command and control network embodied in the Maximum Grain Revenue Entitlement (aka revenue cap), which limited the earning capacity of the two Class 1 Railways from Prairie grain transport (Prentice and Parsons 2015). Arguing that there was no difference between the movement of grain and other commodities such as forest products or coal, the Report recommended phasing out the revenue cap and other restrictions within seven years to produce a 'more commercially grounded' supply chain (Emerson Report 2015, 159-60). Among a series of accompanying five-year modernization initiatives the Report recommended that: containerized rail movements should be excluded from maximum revenue calculations; and the railways should be allowed to set aside onethird of their rail car fleet for which shippers pay 'freight premiums' for guaranteed supply and service. Also, if the revenue cap was removed, arguably there would be a stronger case, as espoused by Burrows (2016), for requiring the railways to replace the aging government-owned grain hoppers.

In November 2016 the Minister of Transport in the incoming Liberal (Justin Trudeau) Government announced the Transportation 2030 strategic plan with trade corridors to global markets being a major theme (Transport Canada 2016). The plan's overriding aim is to improve the transportation system's performance to grow Canada's economy by getting products such as grain to market as expeditiously as possible. Proposals included investing in infrastructure capacity and reducing supply chain congestion, establishing a new data regime, exploring new financial possibilities for financing infrastructure, addressing bottlenecks in trade corridors, providing greater transparency in the rail sector, and ensuring that they complement Pan-Canada initiatives focused upon clean growth, climate change and innovation. However, bearing in mind the damage occasioned to producers during the 2013-14 Crisis, the new strategic plan stopped short of deregulating the railways with respect to grain shipments.

On 16 May 2017 the Liberal Government of Canada introduced the Bill C-49, the proposed Transportation 
Modernization Act, which is centered upon improving the reliability of the rail freight system for handling grain. Key measures specified included allowing the Fair Grain for Farmers Act to expire; instituting reciprocal financial penalties in arbitrated service level agreements with grain companies and the railways; maintaining the Maximum Revenue Agreement; seeking greater transparency in data sharing by empowering Transport Canada to collect information on grain movements and permitting it to intervene when a system failure occurs; and renewing the Crop Logistics Working Group's mandate (CLWG 2017). By December 2017 the Bill had received its Third Reading in the House of Commons and Second Reading in the Senate before being referred to the Standing Senate Committee on Transport and Communications (Parliament of Canada 2017). Whether these proposed changes will provide the elusive permanent fix to perennial crises in the grain logistics system is, therefore, still open to question.

\section{Aftermath: The years following the crisis}

After the Great Canadian Logistics Crisis Western Canada's grain production plus carryover from the preceding year declined from the record 81.2 million tonnes in 2013-14 to 77.1 million tonnes in 2014-15 and 73.9 million tonnes in 2015-16, but recovered to 80.1 million tonnes in 2016-17 - the second highest on record (Quorum Corporation 2016, 2017b, 2018). While this mass of grain still continued to present challenging logistics issues, the system had reportedly responded effectively and efficiently to set new standards in 2014-15 and bettered them in 2015-16 and 2016-17 (Quorum Corporation 2016, 64, 2018, 47). Further, the spot price for Spring Wheat given to the producer at the elevator - now considered to be the best gauge of the country's open market conditions - rose from the low of C \$205 per tonne in 2013 14 to $\mathrm{C} \$ 210.00$ in 2014-15, C\$225.48 in 2015-16 and C\$238.75 in 2016-17 (Table 7). However, this spot price was still well below that of over $\mathrm{C} \$ 284.50$ during the 2012-13 crop year due to the progressive decline in the export quotation for wheat from C\$327.12 per tonne in 2013-14 to C\$323.38 in 2014-15 and C\$297.83 in 2015-16. Although a recovery in the export quotation to over C\$322,28 per tonne occurred in 2016-17, producers have opted to plant more canola than wheat for the first time ever in the 2017-18 crop year - a reflection both of better world prices for canola and the cheaper costs for moving the crop compared with wheat (Statistics Canada 2017b). As these changes progressively work their way through the logistics system there is a temptation to regard the random shock to the grain supply chain in 2013-14 as an aberration triggered by an unusually large crop.

Table 7. Calculation of the average spot price for 1canada red spring wheat, crop years 2013-14, 2014-15, 2015-16 and 2016-17

(C\$/tonne)

\begin{tabular}{|c|c|c|c|c|}
\hline & 2013-14 & $2014-15$ & $2015-16^{1}$ & 2016-17 \\
\hline Export quotation & 327.12 & 323.38 & 297.83 & 322.28 \\
\hline Price differential $^{2}$ & -122.12 & -113.38 & -72.35 & -83.53 \\
\hline Spot price & 205.00 & 210.00 & 225.48 & 238.75 \\
\hline
\end{tabular}

${ }^{1}$ The figures in the 2015-16 Report were revised in the 2016-17 Report.

${ }^{2}$ The price differential covers the cost of freight, handling, cleaning, storage, weighing and inspection, together with an opportunity cost or risk premium. Source: Quorum 2015b, 2016, 2017, 2018.

But what if this situation is not the case and there is another random shock to the logistics system derived from an increase in grain production in response to the growth of markets in the Asia-Pacific region? Then the 2013-14 Crisis, as the new normal, continues to raise some important questions about free markets and government intervention in grain logistics operations. This dilemma involves a choice between the free market fundamentalist who wants to eliminate all regulation and the interventionist who wishes to return to price stability for rural producers. On the one hand the demise of the Canadian Wheat Board has been seen as triggering an acceleration of investment in export grain capacity by the $\mathrm{ABCD}+\mathrm{G}$ Group of Companies, typified by Bunge Inc. acquiring the Board's remaining assets in the Global Grain Group (G3), a joint venture with the Saudi Agriculture and Livestock Invest Co. (SALIC) (Owram 2016); and on the other hand some Prairie farmers in the Canadian Wheat Board Alliance are clamouring for the Board's restoration to reinstate greater Canadian control over the supply chain (MacDonald 2014, Larsen 2016).

Our position, derived from studying the Great Canadian Grain Logistics Crisis of 2013-14 and its aftermath, is to land somewhere between free market fundamentalism and old-style interventionism. This stance stems from the increasingly oligopolistic nature of many segments of the global value chain, and resultant changes in the size, distribution and accessibility to the grain elevator, rail car and port terminal capacity. Where the producers are located in an area with only one or two primary elevators and a single rail operator, they have little bargaining capacity. Unlike their counterparts in Western Australia, for example, the producers have no links with the buyers to give them a stake in the efficiency of the supply chain (White et al. 2015). Consequently, their responses to improved technologies, crops and varieties, and climate change could therefore be restricted by their limited marketing power. Also investments in farm expansion, new machinery and innovations could be constrained by diminishing capital returns. As these issues involve the case for increased grain export capacity and an assessment of the effectiveness of regulatory structures and transport policy, these strategic tasks need to be urgently addressed by the Government of Canada, provincial governments and primary industry. 
An important contribution is anticipated from the Government of Canada's Crop Logistics Working Group's fourth mandate in May 2017 to:

(1) Provide agricultural stakeholders a forum to discuss ongoing issues in the grain handling and transportation system, in the context of the Government's long-term transportation agenda.

(2) Provide a venue for collaboration among agriculture sector stakeholders throughout the supply chain to help improve the efficiency and predictability in how grains and oilseeds move from farm to customer, in Canada or around the globe.

(3) Help ensure Canadian farmers can continue to get their products to markets around the world quickly and efficiently, generating growth for the Canadian economy, putting more money in the pockets of farmers, and strengthening the middle class (Government of Canada 2017).

A conclusive test of the Group's mandate will be the degree to which it succeeds in crisis-proofing Canada's grain logistics system.

In 2018 a positive note has been the expenditure by Canadian National (CN 2018) of C\$320 million to strengthen Alberta's rail infrastructure so that it can respond to any surge in demand. Not only is the company seeking to increase the reliability of its network by purchasing 200 locomotives to renew it fleet but also it has pledged to hire 1,250 extra drivers.

\section{Conclusion}

At the outset, this study of the Great Canadian Grain Logistics Crisis of 2013-14 and its aftermath raised a series of issues straddling international logistics and trade. A global value-chain analysis of these issues has shown that the Crisis exposed Canada's position as a reliable participant in the global grain supply chain, particularly in the Asian-Pacific markets. In 2012, when the Canadian Wheat Board was the country's main organization for exporting wheat and barley to 70 countries, Canada was the second most important grain exporter after the USA with Russia in fifth position. By 2016, after the Crisis, the main wheat exporters in terms of quantity were, in rank order, Russia, the United States and Canada (FAO 2018). Also, the analysis has revealed that Canada's new privatized grain system has imposed the complex interplay between the price of grain, contract design, inventory control, transport cost and infrastructure upon participants in the supply chain. Indeed, the analysis has highlighted how the economic stakeholders - grain companies, railways, port terminal operators, and export buyers and users - have sought to sustain their competitiveness by repositioning their activities within the international economy and constantly adapting their activities to changes in world economic geography. Some producers have responded to the lower returns triggered by the Crisis by switching from wheat to canola. In turn, the Government of Canada has reacted by pinpointing the shortcomings of the railways, because the latest Crisis was essentially one of logistics rather than speculation about the value of grain. Simply increasing the cost of transport provision would not have resolved the Crisis.

More generally, our analysis has important implications for studying international grain supply and demand by demonstrating that shipments must be analyzed within the broader context of overcoming vulnerability in the supply chain to achieve traffic fluidity. As far as the international supply of grain is concerned, a better understanding of the global network economy is required in terms of industry concentration and corporate cross-participation. In particular, an examination of both capital ownership and management type is needed to understand the grip exerted by key players over the grain supply chain. As the capital costs of producing and processing grain have escalated during the period under review, changes have occurred in the financing of crop development. Now this development is only likely to occur with the active participation of global logistics firms, international financing organizations, multinational corporations and governments in producing countries. On the demand side, this study has shown that due account has to be taken of excess capacity stemming from the occurrence of a bumper crop. This has resulted in contractual terms of traded grain being adjusted between importers and exporters in line with the shift from long-term contracts to agreements with recessiontype clauses. However, this shift masks variations in the rates of growth in the demand for grain worldwide. Thus, this study has demonstrated that grain movements provide an important marker of global economic processes in international logistics and trade.

\section{Acknowledgements}

Thanks are due to comments by unknown readers; Samuel Duchesne, Department of Geography, University of Montreal for research assistance; Christopher May, Document Delivery \& Collection Management Assistant, Publications and Collection Management, Knowledge Services Agriculture and Agri-Food Canada, Government of Canada for information on the Crop Logistics Working Group; Mei Yu, Statistical Clerk, Market and Industry Services Branch 
Agriculture and Agri-Food Canada, Government of Canada for information on the number of Prairie grain and oilseed producers and value of their output in the crop year 2013-14; the Noun Project for icons used in Figure 2; and Dr Sue Rimmer for comments on the text.

\section{References}

Archer-Daniels-Midland Company, 2017. ARCHER DANIELS MIDLAND CO (ADM.) SEC Filing 10-K Annual report for the fiscal year ending Saturday, December 31, 2016. Available at https://www.last10k.com/sec-filings/adm/0000007084-16-000046.htm\# fullReport (accessed 6 July 2017).

Briere, K., 2012. Viterra sale in the hands of regulators, Western Producer, 29 March. Available at http://www.producer.com/2012/03/ viterra-sale-in-hands-of-regulators\%E2\%80\%A9/ (accessed May 28 2016).

Brewin, D.G., 2016. Presidential Address: Competition in Canada's agricultural value chains: the case of grain, Canadian Journal of Agricultural Economics, 64, 5-19.

Brewin, D., Nolan J., Gray R., Schmitz T', Schmitz A., 2017. The Canadian handling supply chain in the post Canadian Wheat Board era, Transportation Research Board 17-000784. Available at http://docs.trb.org/prp/17-00784.pdf (accessed 1 January 2018).

Bunge Limited, 2017. Form 10-K Commission File Number 001-16625. Washington, DC: United States Securities and Exchange.

Burrows, B., 2016. The weak link in Canada's grain system, The Hill Report, 11 April 2016, 18. Available at http://tactix.ca/thoughtleadership/PDF/Bruce-Burrows-Hill-Times-Railway-Cars.pdf (accessed 17 May 2016).

Canada Grain Commission, 2013. Grain Elevators in Canada, Crop Year 2013-14 as at August 1, 2013. Available at http://www.grai nscanada.gc.ca/statistics-statistiques/geic-sgc/2013-08-01.pdf (accessed 19 January 2018).

Canadian Grain Commission, 2017a. Grain Elevators in Canada Statistics by Crop Year, 2009-2010 to 2016-2017. Available at https: //www.grainscanada.gc.ca/wa-aw/geic-sgc/search-recherche-eng.asp (accessed 31 December 2017).

Canadian Grain Commission, 2017b. Canadian Grain Exports (Annual): Annual Crop Year Data 2013-14. Available at https://www. grainscanada.gc.ca/statistics-statistiques/cge-ecg/cgem-mecg-eng.htm (accessed 14 December 2017).

Cargill Inc., 2017. 2017 Annual Report: Momentum. Available at https://www.cargill.com/doc/1432094802973/2017-annualreport.pdf (accessed 31 December 2017).

CCGA, 2015. Agriculture can grow our economy but rail service must respond to market demand, CCGA Release. Winnipeg MB and Ottawa ON: Canadian Canola Growers Association (CCGA). Available at http://www.ccga.ca/policy/Documents/Rail\%20 Service\%20Must\%20Meet\%20Demand\%20Insert\%20June\%202015.pdf (accessed 25 January 2018).

Clapp, J., 2015. ABCD and beyond: From grain merchants to agricultural value chain managers, Canadian Food Studies, 2, 126-135.

CLWG, 2014. Crop Logistics Working Group: Final Report 2014. Ottawa, ON: Agriculture and Agri-Food Canada, Government of Canada. Available on request.

CLWG, 2015. Crop Logistics Working Group Submission to the Canada Transportation Act Review. Ottawa, ON: Agriculture and Agri-Food Canada, Government of Canada. Available on request.

CLWG, 2017. Crop Logistics Working Group. Ottawa, ON: Agriculture and Agri-Food Canada, Government of Canada. Available at http://www.agr.gc.ca/eng/industry-markets-and-trade/market-information-by-sector/crops/initiatives-supporting-crop-producers /crop-logistics-working-group/?id=1323987063552 (accessed 15 January 2018).

CN, 2018. CN investing \$320 million to expand and strengthen Alberta's rail infrastructure in 2018, Edmonton, Alberta, 12 January 2018. Available at https://www.cn.ca/en/news/2018/06/cn-investing-\$320-million-to-expand-and-strengthen-albertas-rail/ (accessed 22 July 2018).

Coe, N.M., Dicken, P., Hess, M., 2008. Global production networks: realizing the potential, Journal of Economic Geography, 8, 271295.

Doan, D., Paddock, B., Dyer, J., 2006. The reform of grain transportation policy and transformation in Western Canadian agriculture', in D. Blandford and B. Hill (eds), Policy Reform and Adjustment in the Agricultural Sectors of Developed Countries. CAB International (CABI): Wallingford, UK and Cambridge, MA., 163-174.

Earl, P.D., 2015. From free markets to regulation and back again: cycles in transportation grain marketing and economic thought, Canadian Transportation Research Forum 50th Annual Conference - Another 50 Years: Where to From Here?//Un autre 50 ans: qu'en est-il à partir de maintenant? Montreal, QC, Canada. Available at http://ctrf.ca/wpcontent/uploads/2015/05/CTRF2015Ear 1FreightRail.pdf (accessed 26 September 2017).

Emerson Report, 2015. Canada Pathways: Connecting Canada's Transportation System to the World, Canada Transportation Act Review, 2 volumes. Ottawa, ON: Government of Canada. http://www.tc.gc.ca/eng/ctareview2014/CTAR_Vol2_EN.pdf (accessed 28 May 2016).

Estey, Hon. W.Z., 1998. Grain Handling and Transportation Review: Final Report to the Minister of Transport. Available at http://data.tc.gc.ca/archive/eng/policy/report-acg-esteygrainii-phase_ii_final_report-227.htm (accessed 15 June 2017).

FAO, 2018. FAOSTAT: Pays per products, Organisation des United Nations pour l'alimentation et l'agriculture. Accessed 20 July 2018. Available at http://www.fao.org/faostat/fr/\#rankings/countries_by_commodity_exports (accessed 20 July 2018).

Gereffi G., Korzeniewicz, M., 1994. Commodity Chains and Global Capitalism, Westport, CT: Praeger.

Gereffi, G., Fernandez-Stark, K., 2011. Global Value Chain Analysis: A Primer. Durham, NC: Center on Globalization Governance and Competitiveness (CGGC), Duke University. Available at https://www.researchgate.net/ publication/265892395_Global_ Value_Chain_Analysis_A_Primer (accessed 28 January 2018).

Gereffi, G., Fernandez-Stark, K., 2016. Global Value Chain Analysis: A Primer (2nd Edition). Durham, NC: Center on Globalization Governance and Competitiveness (CGGC), Duke University. Available at https://globalvaluechains.org/publication/globalvalue-chain-analysis-primer-2nd-edition (accessed 28 January 2018).

Gereffi, G., Kaplinsky, R., (eds), 2001. The value of value chains: spreading the gains from globalization, Special Issue, Institute of Development Studies Bulletin, 32, 1-136. 
Gilson, J.C., 1982. Western Grain Transportation, Report on Consultations and Recommendations, Ottawa, ON: Minister of Supply and Services.

Government of Canada, 2013. Fair Rail Freight Service Act S.C. 2013, c. 31 Assented to 2013-06-26'. Justice Laws Website. Available at http://laws-lois.justice.gc.ca/eng/AnnualStatutes/2013.31page-1.html (accessed 18 July 2018).

Government of Canada, 2014. Fair Rail for Grain Farmers Act S.C 2014 c. 8 Assented to 2014-05-29'. Justice Laws Website. Available at http://laws-lois.justice.gc.ca/eng/annualstatutes/2014_8/page-1.html (accessed 31 December 2017).

Government of Canada, 2017. Crop Logistics Working Group. Ottawa: Agriculture and Agri-Food Canada. Available at http://www. agr.gc.ca/eng/industry-markets-and-trade/canadian-agri-food-sector-intelligence/crops/initiatives-supporting-crop- producers/ crop-logistics-working-group/?id=1323987063552 (accessed 18 July 2018).

Gray, R., 2015. The Economic Impact of Elevated Export Business Levels on Western Canadian Grain producers 2012/13, 2013-14 and 2014/15. Regina, SK: Saskatchewan Wheat Development Commission.

Gruending, D., 2012. Viterra kills Sask Wheat Pool legacy. Available at http://www.dennisgruending.ca/2012/04/viterra-kills-saskwheat-pool-legacy (accessed 26 May 2016).

Hall Commission Report, 1977. Grain and Rail in Western Canada: The Report of the Grain Handling and Transportation Commission, Volumes I and II, Winnipeg MB: Hall Commission.

Hall, P., McCalla, R.J., Comtois, C., Slack, B., (eds), 2010. Integrating Seaports and Trade Corridors. Farnham, UK, and Burlington, VT, USA: Ashgate Publishing Ltd.

Johnson, K., 2014. Grain jam: Five reasons why the grain crisis matters to you, ipolitics 19 February 2014. Available at http://ipolitics.ca/2014/02/19/grain-jam-five-reasons-why-the-grain-crisis-matters-to-you (accessed 26 June 2017).

Kerr, W.A., Fox, G., Hobbs, J.E., Klein, K.K., 1991. A review of studies on Western Canadian grain transportation, Working Paper 6/91, Ottawa, ON: Grains and Oilseeds Branches Agriculture Canada. Available at http://ageconsearch.umn.edu/ bitstream/244 072/2/aafc-wppb-06-91.pdf (accessed 15 June 2017).

Kroeger, A., 2009. Retiring the Crow Rate: A Narrative of Political Management. Edmonton, AB: University of Alberta Press.

Larsen, L., 2016. A report prepared for the Canadian Wheat Board Alliance. 13 March 2016. Revised 17 April 2016. Available at http://www.cwbafacts.ca/wp-content/uploads/2016/04/Evaluation-of-present-situation-for-Western-Canadian-grain- farmers revised.pdf (accessed 11 January 2018).

LDC, 2017. Louis Dreyfus Company: A New Perspective, Annual Report 2016. Available at http://www.ldcom.com/files/6414/9121/ 7174/LDC-AR-2016 (accessed 7 July 2017).

Leslie, D., Reimer, S., 1999. Spatializing commodity chains, Progress in Human Geography, 23, 401-429.

MacDonald, J., 2014. Why so many farmers miss the wheat board, Globe and Mail, 27 November 2014 (updated 5 June 2017). Available at https://www.theglobeandmail.com/report-on-business/rob-magazine/why-so-many-farmers-miss-the-wheat- board/ article21810531/ (accessed 2 January 2017).

Marowits, R., 2014. Canada grain crisis: CN delivered 5,100 cars to elevators, Toronto Metro, 1 April 2014. Available at http://www. metronews.ca/news/canada/2014/03/31/canada-grain-crisis-cn-delivered-5100-cars-to-elevators.html (accessed 17 January 2018)

Miner, W.M., 2015. The rise and fall of the Canadian Wheat Board, CAES Fellows Paper 2015-2. Available at http://www.grainmoit or.ca/Downloads/AnnualReports/AnnualReport201516.pdf (accessed 28 January 2018).

Nickel, R., Howley, V., 2012. Viterra opens books to potential buyers, shares jump, Financial Post, 15 March 2012. Available at https://financialpostbusiness.files.wordpress.com/2012/03/fp0316_viterra940.jpg (accessed 22 May 2016).

Nolan, J., Peterson, S., 2015. Grain handling and transportation policy in Canada: implications for the United States, Choices, 30, 1-9. Available at http://www.choicesmagazine.org/UserFiles/file/cmsarticle_442.pdf (accessed 21 June 2017).

Owram, K., 2016. A rich harvest: How the Canadian Wheat Board's demise unleashed a grain bonanza, Financial Post, 17 October 2016. Available at http://business.financialpost.com/transportation/a-rich-harvest-how-the-canadian-wheat-boards-demiseunleashed-a-grain-bonanza (accessed 15 June 2017).

Parliament of Canada, 2017. C-49 Transportation Modernization Act (short title), House Government Bill, 42nd Parliament 1st Session. Available at https://www.parl.ca/LegisInfo/BillDetails.aspx?billId=8945674\&Language=E (accessed 31 December 2017).

PG, 2016. Paterson Grain. Available at http://www.patersongrain.com/about (accessed 24 May 2016).

P\&H, 2009. Parrish and Heimbecker, Limited: Celebrating 100 Years 1909-2009. Brochure. Available at http://www.parrishandheim becker.com/P\&H\%20Brochure\%20100th\%20Anniversary\%20\%282009\%29\%20web\%20version.pdf (accessed 25 May 2016).

P\&H, 2016. Parrish and Heimbecker, Limited. Winnipeg, MB. Available at http://www.parrishandheimbecker.com/home (accessed 24 May 2016).

Pedwell, T., 2014. Canada's international reputation as a reliable grain producer is on the line, The Star, 24 March 2014.

Prabhu, M.A., 1971. Freight rate regulation in Canada, McGill Law Journal, 17, 292-359.

Prentice, B., Parsons, G., 2015. Freedom in Western Grain Movement: A Summary Assessment of the Effect of the Maximum Grain Revenue Entitlement (A.K.A. Revenue Cap) on Railway Efficiency, Growth \& Productivity in the Western Canadian Grain Handling \& Transportation System. Available at http://www.railcan.ca/assets/images/CTA_Review/Appendix_C_ _Freedom_in_Western_Grain_Movement.pdf (accessed 28 May 2016).

Quorum Corporation, 2002. Grain Monitoring Program: Base Monitoring Program/ Report on the Development and Formulation of a Methodology for the Calculation of Producer Netback Measures. Available http://www.quorumcorp at.net/Downloads/Supplem entalReports/ProducerNetback.pdf (accessed 3 February 2018).

Quorum Corporation, 2013. Annual Report 2011-12 Crop Year: Monitoring the Canadian Grain Handling and Transportation System. Edmonton, AB: Quorum Corporation. Available at http://www.quorumcorp.net/Downloads/AnnualReports/AnnualRe port201112.pdf (accessed 14 November 2017).

Quorum Corporation, 2014. Annual Report 2012-13 Crop Year: Monitoring the Canadian Grain Handling and Transportation System. Edmonton, AB: Quorum Corporation. Available at http://www.quorumcorp.net/ Downloads/AnnualReports/AnnualRe port201213.pdf (accessed 14 November 2017).

Quorum Corporation, 2015a. Canada's Western GHTS: A Review of the Past Two Years, Farmers Forum, Saskatoon, 20 July 2015. 
Available at http://saskbarleycommission.com/wp-content/uploads/2015/07/Hemmes.pdf (accessed 19 January 2018).

Quorum Corporation, 2015b. Annual Report 2013-14 Crop Year: Monitoring the Canadian Grain Handling and Transportation System, Edmonton. AB: Quorum Corporation. Available at http://www.quorumcorp.net/Downloads/AnnualReports/AnnualRe port201314.pdf (accessed 14 November 2017).

Quorum Corporation, 2016. Annual Report 2014-15 Crop Year: Monitoring the Canadian Grain Handling and Transportation System/ Edmonton AB: Quorum Corporation. Available at http://www.quorumcorp.net/Downloads/AnnualReports/AnnualRe port201415.pdf (accessed 14 November 2017).

Quorum Corporation, 2017a. Grain Monitoring Program: The GHTS at a Glance, Key Measures for 1999-2016. Edmonton, AB: Quorum Corporation. Available at http://www.grainmonitor.ca/Downloads/AnnualReports/GHTS_Glance20152016.pdf (accessed 14 November 2017).

Quorum Corporation, 2017b. Annual Report 2015-2016 Crop Year: Monitoring the Canadian Grain Handling and Transportation System, Edmonton, AB: Quorum Corporation. Available at http://www.grainmonitor.ca/Downloads/AnnualReports/AnnualRe port201516.pdf (accessed 14 November 2017).

Quorum Corporation, 2018. Annual Report 2016-2017 Crop Year: Monitoring the Canadian Grain Handling and Transportation System, Edmonton, AB: Quorum Corporation. Available at http://www.grainmonitor.ca/reports.html\#AnnualReports (accessed 22 July 2018).

Richardson, 2016. Richardson Pioneer: About us. Available at http://www.richardson.ca/products-and-services/pioneer (accessed 22 May 2016).

Rimmer, P.J., 2014. Asian Pacific Rim Logistics: Global Context and Local Politics. Cheltenham UK and Northampton, MA, USA: Edward Elgar Publishing.

Schmitz, A.W., Furtan, H., 2000. The Canadian Wheat Board: Marketing in the New Millennium, Regina, SK: University of Regina. Canadian Plains Research Center.

Silcoff, S., 2017. Growing up Richardson, Report on Business: Globe and Mail, November 2017, 26-35.

Statistics Canada, 2017. 2016 Census of Agriculture 2016: Canada and provinces. Ottawa, ON: Statistics Canada. Available at https://www.statcan.gc.ca/eng/ca2016 (accessed 18 January 2018).

Statistics Canada, 2017b. Principal field crop areas, June 2017, released 2017-06-29. Ottawa, ON: Statistics Canada. Available at http://www.statcan.gc.ca/daily-quotidien/170629/dq170629c-eng.htm (accessed 27 December 2017).

Sturgeon, T.J., 2001. How do we define value chains and production networks?, IDS Bulletin, 32, 9-18.

Sturgeon, T.J., 2008. From commodity chains to value chains: Interdisciplinary theory building in an Age of Globalization', in J. Bair (ed.), Frontiers of Commodity Chain Research. Stanford, CA: Stanford University Press, 110-135.

Torshizi, M., Gray. R., 2017. An economic analysis of Western Canadian grain capacity', Canadian Journal of Agricultural Economics. Available at http://onlinelibrary.wiley.com/doi/10.1111/cjag.12148/abstract (accessed 28 January 2018).

Transport Canada, 2001. Appendix: Monitoring the Canadian Grain Handling and Transportation System. Ottawa, ON: Transport Canada. Available at http://data.tc.gc.ca/archive/eng/policy/report-acg-grainmonitoringprogram-ghts_appendix-228.htm (accessed 28 May 2016).

Transport Canada, 2016. Transportation 2030 - A Strategic Plan for the Future of Transportation in Canada. Ottawa, ON: Transport Canada. Available at https://www.canada.ca/en/transport-canada.html (accessed 14 November 2017).

White, P., Carter, C., Kingwell, R., 2015. The Puck Stops Here! Canada Challenges Australia Supply Chains. Perth: Australia Export Grains Innovations Centre (AEGIC).

Wilson, C., 1978. A Century of Canadian Grain: Government Policy to 1951. Saskatoon, SK: Western Producer Prairie Book. 